\title{
PENGEMBANGAN MODELDISCOVERY LEARNING USING SURVEY PADA MATERI FUNGI SMA KELAS X MIPA
}

\author{
Rini Setyowati ${ }^{1}$, Sajidan ${ }^{2}$, Puguh Karyanto ${ }^{3}$ \\ ${ }^{1}$ Program Studi Magister Pendidikan Sains FKIP Universitas Sebelas Maret \\ Surakarta, 57126, Indonesia \\ setyowatirini98@gmail.com \\ ${ }^{2}$ Program Studi Magister Pendidikan Sains FKIP Universitas Sebelas Maret \\ Surakarta, 57126, Indonesia \\ adjid2002@yahoo.com \\ ${ }^{3}$ Program Studi Magister Pendidikan Sains FKIP Universitas Sebelas Maret \\ Surakarta, 57126, Indonesia \\ karyarina@yahoo.com
}

\begin{abstract}
Abstrak
Tujuan penelitian dan pengembangan yaitu untuk mengetahui : 1) Karakteristik model Discovery Learning Using Survey pada materi jamur di SMA Negeri I Jogorogo Ngawi, 2) Kelayakan model Discovery Learning Using Survey pada materi jamur di SMA Negeri I Jogorogo, 3) Kefektifan model Discovery Learning Using Survey terhadap hasil belajar siswa SMA Negeri I Jogorogo. Penelitian ini menggunakan metode Research And Development ( R \& D) mengacu pada model Borg \&Gall yang telah dimodifikasi. Kelayakan model divalidasi oleh ahli model, ahli materi, dan guru biologi (praktisi). Subjek uji coba pada penelitian ini adalah siswa kelas X MIA dengan rincian 23 research and information collection, 15 siswa untuk tahap main field testing dan 57 siswa untuk tahap operasional field testing. Hasil penelitian dan pengembangan menunjukkan : 1) Karakteristik model Discovery Learning Using Survey dilakukan dengan memperhatikan karakteristik dari model yaitu adanya sintaks, sistem sosial, sistem pendukung, peran siswa, peran guru, dampak instruksional, dan dampak pengiring, 2) hasil pengembangan model Discovery Learning Using Survey layak untuk diterapkan pada materi fungi. Kelayakan model Discovery Learning Using Survey berdasarkan penilaian dari ahli, praktisi, dan respon siswa yang secara keseluruhan memberikan kategori sangat baik pada produk pengembangan dan layak digunakan di SMA Negeri I Jogorogo, 3) model Discovery Learning Using Survey sangat efektif serta mampu meningkatkan hasil belajar siswa. Hasil penelitian menunjukkan ada perbedaan yang signifikan dari rerata hasil belajar antara kelas baseline dengan kelas uji coba dengan penggunaan model Discovery Learning Using Survey lebih baik dibandingkan dengan kelas baseline yang menggunakan model ceramah bervariasi.
\end{abstract}

Kata kunci : discovery learning ,SQ3R, Discovery Learning Using Survey, fungi

\section{Pendahuluan}

Kurikulum 2013 atau K-13 bahwa pembelajaran menggunakan pendekatan ilmiah (scientific), tematik terpadu (tematik antar mata pelajaran), dan tematik (dalam suatu matapelajaran) dengan model pembelajaran berbasis penyingkapan/ penelitian (discovery /inquiry learning). Sasaran pembelajaran mencakup pengembangan ranah sikap, pengetahuan, dan keterampilan yang dielaborasi untuk setiap satuan pendidikan. Ketiga ranah kompetensi tersebut memiliki lintasan perolehan (proses psikologis) yang berbeda. Sikap diperoleh melalui aktivitas“" menerima, menjalankan, menghargai, menghayati, dan mengamalkan". Pengetahuan diperoleh melalui aktivitas" mengingat, memahami, menerapkan, menganalisis, mengevaluasi, mencipta. Keterampilan diperoleh melalui aktivitas“ mengamati, menanya, mencoba, menalar, menyaji, dan mencipta”. 
Biologi sebagai ilmu yang mempunyai karakteristik yang berbeda dibandingkan dengan ilmu yang lain, perbedaannya terletak pada kompleksitas komponen pembelajaran yang meliputi proses, produk dan sikap. Salah satu hakikat Biologi adalah pengamatan yang menggunakan indera, menggolongkan atau mengelompokkan, menerapkan konsep atau prinsip, menggunakan alat dan bahan, berkomunikasi, berhipotesis, menafsirkan data, melakukan percobaan, dan mengajukan pertanyaan yang akan menghasilkan suatu produk. (Hand out materi pelatihan Implementasi K 13, Kemendikbud)

Peran guru tidak sebagai penyampai materi melainkan sebagai fasilitator yang membantu siswa dalam memahami dan memecahkan masalah serta menemukan sendiri konsep yang sedang dipelajarinya. Kompetensi pedagogik guru perlu dimunculkan untuk memilih suatu model pembelajaran yang tepat bagi peserta didik.(Trianto,2009).

Hasil observasi yang dilakukan di SMAN 1 Jogorogo menunjukkan bahwa hasil survei skor pemenuhan 8 komponen Standar Nasional Pendidikan (SNP) diperoleh skor komulatif sebesar 86,57\% merupakan kategori baik sedangkan Gapnya 13,43 \%. Gap terbesar terletak pada Standar Proses sebesar 3,24\% dan standar sarana prasarana sebesar 3,24\%.Sedangkan nilai rata-rata Ujian Nasional mata pelajaran Biologi belum stabil dari tahun ketahun, bahkan masih perlu peningkatan yang signifikan;

\begin{tabular}{ccc}
\hline NO & TAHUN & $\begin{array}{c}\text { Daya Serap KD } \\
\text { Fungi }\end{array}$ \\
\hline 1 & $2007-2008$ & 8,55 \\
\hline 2 & $2008-2009$ & 8,44 \\
\hline 3 & $2009-2010$ & 6,68 \\
\hline 4 & $2010-2011$ & 6,72 \\
\hline 5 & $2011-2012$ & 7,16 \\
\hline
\end{tabular}

(sumber Data Pamer Kemendikbud, Th 2008, 2009, 2010, 2011 dan 2012)

Fakta dilapangan pembelajaran disekolah cenderung teacher center yaitu guru menggunakan metode ceramah, siswa hanya sebagai penerima konsep, tidak membangun konsep dengan sendirinya maka diperlukan perubahan model pembelajaran dari teacher center menjadi student center yaitu pembelajaran Discovery atau penemuan, selain siswa menemukan konsep sendiri dia akan menyimpan penemuan konsep itu dalam memori jangka panjang.(Silberman, 2002)

Dari hasil Observasi tersebut berarti keterampilan proses sains perlu dilatihkan seperti yang dituntut dalam Kurikulum 2013. Siswa perlu dibantu untuk menemukan konsep biologi dan menguasai keterampilan proses sains, sehingga memerlukan suatu metode atau model pembelajaran yang dapat membantu guru dan siswa memperoleh hasil maksimal dalam proses pembelajaran. (Permendikbud No.59 Tahun 2014)

Model pembelajaran yang tepat digunakan dalam kegiatan pembelajaran Biologi di SMA adalah model pembelajaran yang menempatkan siswa sebagai pusat kegiatan (student centered learning), yaitu dengan membimbing mereka untuk berdiscovery atau menemukan baik permasalahan yang ada dan pemecahannya serta tidak terlepas dari karakteristik Biologi sebagai Ilmu yaitu meliputi proses, produk dan sikap. Dalam pembelajaran dengan model discovery, siswa di samping menguasai konsep biologi, siswa dapat dilatih untuk meneliti suatu permasalahan atau pertanyaan dengan fakta-fakta yang ada. Pembelajaran biologi yang melibatkan kemampuan discovery siswa meliputi: kegiatan menghimpun informasi, membandingkan, mengkategorikan, menganalisis, mengintegrasikan, mereorganisasikan bahan serta membuat kesimpulan-kesimpulan. (Illahi, 2012)

Penelitian oleh Mirza Faizal Hamid (2013) menyatakan bahwa terdapat pengaruh yang signifikan pengembangan Perangkat pembelajaran menggunakan model Guided Discovery terhadap hasil belajar system pengendalian elektromagnetik di SMK Negeri 2 Surabaya. Selanjutnya, penelitian oleh Indah Rosmalia (2011) menyatakan bahwa penerapan bahan ajar berbasis penemuan member pengaruh yang posistif terhadap hasil belajar siswa. Sehingga, salah satu upaya yang dilakukan untuk membantu guru dan siswa dalam penerapan kurikulum 2013 di sekolah adalah dengan mengembangkan model Discovery Learning Using Survey pada materi Fungi yang merupakan bagian dari materi biologi. 


\section{Metode Penelitian}

Tempat pelaksanaan uji coba lapangan produk adalah di SMA Negeri 1 Jogorogo Ngawi yang beralamat di Jalan Raya Jogorogo Ngawi. Penelitian pengembangan yang dilakukan menggunakan model prosedural dengan mengadaptasi model pengembangan Borg \& Gall (1983) yang telah dimodifikasi. Subyek penelitian yaitu 2 Guru Biologi, Wakasek Kurikulum, dan siswa kelas X MIA dengan rincian 23 siswa sebagai partisipan, 15 siswa untuk tahap uji terbatas dan 57 siswa untuk tahap uji lapangan..

Tehnik pengambilan data dalam penelitian pengembangan ini menggunakan: 1) Research and Information Collection (tahap analisis kebutuhan), 2) Preliminary Field Test( tahap validasi oleh tim ahli), 3) Main Field Testing( tahap validasi oleh praktisi pendidikan), 4) Operasional Field Testing (tahap uji coba Lapangan). Instrumen pelaksanaan penelitian berupa Prototipe Model Discovery Learning Using Survey, silabus, RPP Discovery Learning Using Survey, LKS dan system penilaian. Analisis data yang dilakukan menggunakan dua teknik analisis data yaitu teknik analisis deskriptif dan kuantitatif.

\section{Hasil Penelitian dan Pembahasan}

Hasil penelitian dan pengembangan berupa model pembelajaran Discovery Learning Using Survey dilengkapi data penilaian oleh validator, praktisi dan siswa serta keterlaksanaan sintaks dan hasil belajar aspek pengetahuan, sosial dan keterampilan serta penilaian antar teman sejawat yang dilakukan oleh siswa

Tabel 1. Penilaian Model Oleh validator ahli, praktisi pendidikan dan siswa

\begin{tabular}{llll}
\hline NO & Penilaian Model & nilai & Kategori \\
\hline $\mathbf{1}$ & Validator ahli & $\mathbf{8 6 . 4}$ & Sangat baik \\
$\mathbf{2}$ & Praktisi & $\mathbf{8 8 , 5}$ & Sangat baik \\
& pendidikan & $\mathbf{8 1 , 7}$ & \\
$\mathbf{3}$ & Siswa ( Uji Coba) & & Sangat baik \\
& Siswa ( Uji & & \\
$\mathbf{4}$ & Lapangan) & & Sangat baik \\
\hline
\end{tabular}

Keterangan: penilaian validasi dilakukan 4 validator yaitu ahli materi, ahli model pembelajaran dan ahli perangkat serta praktisi pendidikan

Tabel 2. Hasil Validasi Produk oleh Praktisi

\begin{tabular}{ccccc}
\hline No & Praktisi & $\begin{array}{c}\text { Aspek } \\
\text { Penilaian }\end{array}$ & $\begin{array}{c}\text { Nilai } \\
(\%)\end{array}$ & Kategori \\
\hline 1 & RPP & $\begin{array}{c}\text { Aspek } \\
\text { perangkat } \\
\text { pembelajaran } \\
\text { Penyajian } \\
\text { model, materi, } \\
\text { bahasa } \\
\text { keterbacaan }\end{array}$ & 92 & $\begin{array}{c}\text { Sangat } \\
\text { baik }\end{array}$ \\
& LKS & 87 & $\begin{array}{c}\text { Sangat } \\
\text { baik }\end{array}$ \\
\hline Rata-rata & 88,5 & $\begin{array}{c}\text { Sangat } \\
\text { baik }\end{array}$ \\
\hline
\end{tabular}

Keterangan: penilaian oleh praktisi pendidikan

dilakukan oleh 2 orang guru biologi

Tabel 3. Hasil Uji Coba Lapangan Kelompok Kecil

\begin{tabular}{rlcc}
\hline No & Aspek Penilaian & Nilai $(\%)$ & Kategori \\
\hline 1 & Kemudahan Model & 82 & Baik \\
2 & Kejelasan Model & 84 & Sangat Baik \\
3 & Partisipasi Siswa & 85 & Baik \\
\hline & Rata-rata & $\mathbf{8 1 , 7}$ & Sangat Baik \\
\hline
\end{tabular}

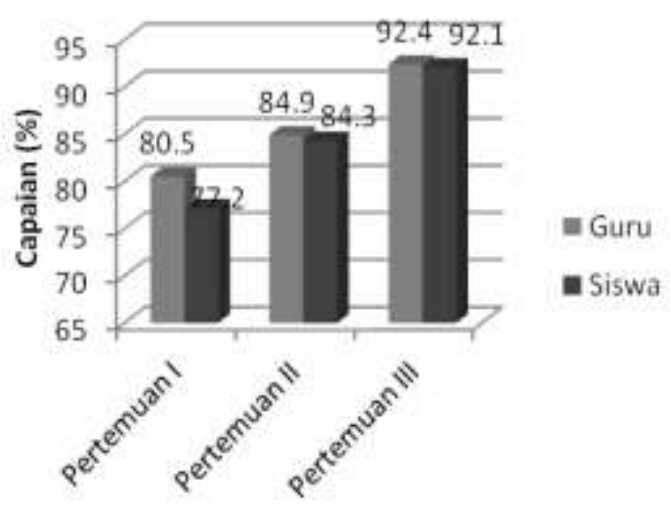

Keterangan: Uji coba kelompok kecil dilakukan secara acak pada siswa kelas X MIA SMAN I Jogorogo Ngawi

Gambar 1. Histogram Keterlaksanaan sintaks oleh guru dan siswa

Berdasarkan data keterlaksanaan sintaks menunjukkan bahwa pada setiap 
kali pertemuan keterlaksanaan sintaks mengalami peningkatan. Pada pertemuan I rerata yang diperoleh dari aktivitas guru adalah $80,5 \%$, pertemuan II sebesar $84,9 \%$ dan pertemuan III sebesar $92,4 \%$ dan keterlaksanaan sintaks oleh siswa juga mengalami peningkatan. Pada pertemuan I rerata yang diperoleh dari aktivitas siswa adalah $77,2 \%$, pertemuan II sebesar $84,3 \%$ dan pertemuan III sebesar $92,1 \%$.

Tabel 4. Hasil Belajar Aspek Pengetahuan

\begin{tabular}{|c|c|c|}
\hline Komponen & $\begin{array}{l}\text { Modelling } \\
\text { Class }\end{array}$ & $\begin{array}{l}\text { Convensional } \\
\text { Class }\end{array}$ \\
\hline $\begin{array}{l}\text { Nilai } \\
\text { Maksimum }\end{array}$ & 96,67 & 93,00 \\
\hline $\begin{array}{l}\text { Nilai } \\
\text { Minimum }\end{array}$ & 70 & 60 \\
\hline Skor rata-rata & 87,00 & 78,00 \\
\hline $\begin{array}{l}\text { Siswa yang } \\
\text { tuntas }\end{array}$ & 33 & 27 \\
\hline $\begin{array}{l}\text { Siswa yang } \\
\text { tidak tuntas }\end{array}$ & 3 & 9 \\
\hline KKM & 75 & 75 \\
\hline
\end{tabular}

Berdasarkan hasil belajar aspek pengetahuaan postest kelas model dan kelas biasa. Dari data di atas diketahui bahwa rerata nilai postest sebesar 87 dengan nilai maksimum 96,67 dan nilai minimum 70 untuk kelas model, sedangkan untuk convensional class sebesar 78 dengan nilai maksimum 90 dan nilai minimum 60,00. Dilihat dari KKM di SMA Negeri 1 Jogorogo Ngawi sebesar 75 maka dari ketuntasan maksimal siswa untuk kelas model sebanyak 30 siswa dan siswa yang tidak tuntas sebanyak 3 dari 32 siswa, sedangkan untuk kelas biasa siswa yang tuntas sebanyak 23 siswa dan siswa yang tidak tuntas sebanyak 9 siswa dari 32 siswa. Rata-rata posttest kelas convensional class lebih rendah dibanding dengan rata-rata posttest kelas model dengan selisih nilai 9,00
Tabel 5. Hasil Belajar Aspek Sikap Spiritual

\begin{tabular}{lcc}
\hline Komponen & $\begin{array}{c}\text { Kelas } \\
\text { Model }\end{array}$ & $\begin{array}{l}\text { Conven } \\
\text { sional } \\
\text { Class }\end{array}$ \\
\hline Nilai Maksimum & 100 & 80 \\
Nilai Minimum & 80 & 75 \\
Skor rata-rata & 80 & 70 \\
Siswa yang tuntas & 20 & 10 \\
Siswa yang tidak & 16 & 26 \\
tuntas & & \\
\hline KKM & $\mathbf{7 5}$ & $\mathbf{7 5}$ \\
\hline
\end{tabular}

Berdasarkan hasil belajar aspek sikap spiritual kelas model dan Convensional Class. Dari data di atas diketahui bahwa rerata nilai sebesar $79,43 \%$ dengan nilai maksimum 100 dan nilai minimum 80 untuk kelas model, sedangkan untuk convensional classs sebesar 70 dengan nilai maksimum 80 dan nilai minimum 75. Dilihat dari KKM di SMA Negeri 1 Jogorogo Ngawi sebesar 75 maka dari ketuntasan maksimal siswa untuk kelas model sebanyak 20 siswa yang tuntas dan yang tidak tuntas sebanyak 12 dari 32 siswa, sedangkan untuk Convensional Class siswa yang tuntas sebanyak 10 siswa yang tuntas dan yang tidak tuntas sebanyak 22 siswa dari 32 siswa.

Tabel 6. Hasil Belajar Aspek Sikap sosial

\begin{tabular}{lccc}
\hline No & Pertemuan & $\begin{array}{c}\text { Kelas } \\
\text { Model }\end{array}$ & $\begin{array}{c}\text { Convensional } \\
\text { class }\end{array}$ \\
\hline 1. & I & 82,94 & 70,07 \\
2. & II & 83,07 & 73,13 \\
3. & III & 91,15 & 75,78 \\
\hline & \%Rata-rata & $\mathbf{8 5 , 7 2}$ & $\mathbf{7 3 , 1 3}$ \\
\hline
\end{tabular}

Berdasarkan hasil persentase penilaian aspek sikap sosial pada kelas model pertemuan pertama (I) sebesar $82,94 \%$, pertemuan kedua (II) sebesar 83,07\% dan pertemuan ketiga (III) sebesar 91,15\%. Secara keseluruhan hasil aspek sikap sosial siswa selama 3 (tiga) kali pertemuan sebesar $85,72 \%$. Persentase penilaian aspek sikap sosial pada convensional class pertemuan pertama (I) sebesar $70,05 \%$, pertemuan kedua (II) sebesar $73,57 \%$ dan pertemuan 
ketiga (III) sebesar 75,78\%. Secara keseluruhan hasil aspek sikap siswa selama 3 (tiga) kali pertemuan sebesar sebesar $73,13 \%$

Tabel 7. Hasil Belajar Aspek Keterampilan.

siswa dari KKM sebesar 75. Pada convensional class diketahui rerata sebesar $84 \%$, nilai maksimum sebesar 90 siswa dan nilai minimum sebesar 70.Jumlah siswa yang tuntas sebanyak 20 siswa, sedangkan siswa yang tidak tuntas sebanyak 16 siswa dari KKM 75.

\begin{tabular}{lccc}
\hline No & Pertemuan & $\begin{array}{c}\text { Kelas } \\
\text { Model }\end{array}$ & $\begin{array}{c}\text { Convensional } \\
\text { class }\end{array}$ \\
\hline 1. & I & 81,03 & 42,53 \\
2. & II & 82,38 & 25,00 \\
3. & III & 83,56 & 25,00 \\
\hline & \% Rata-rata & $\mathbf{8 2 , 3 2}$ & $\mathbf{3 2 , 7 8}$ \\
\hline
\end{tabular}

Berdasarkan hasil belajar aspek keterampilan diketahui bahwa persentase penilaian aspek keterampilan pada kelas model pertemuan pertama (I) sebesar $81,03 \%$, pertemuan kedua (II) sebesar $82,38 \%$ dan pertemuan ketiga (III) sebesar 85,58\%. Secara keseluruhan hasil aspek keterampilan siswa selama 3 (tiga) kali pertemuan sebesar sebesar 82,32\%.Persentase penilaian aspek sikap sosial pada convensional class pertemuan pertama (I) sebesar $42,53 \%$, pertemuan kedua (II) sebesar $25 \%$ dan pertemuan ketiga (III) sebesar 25\%. Secara keseluruhan hasil aspek sikap siswa selama 3 (tiga) kali pertemuan sebesar sebesar 30,84\%

Tabel 8. Hasil penilaian diri siswa.

\begin{tabular}{llcc}
\hline No & Komponen & $\begin{array}{c}\text { Kelas } \\
\text { Model }\end{array}$ & $\begin{array}{c}\text { Convensional } \\
\text { Class }\end{array}$ \\
\hline 1. & $\begin{array}{l}\text { Nilai } \\
\text { maksimum }\end{array}$ & 100 & 90 \\
2. & $\begin{array}{l}\text { Nilai } \\
\text { minimum }\end{array}$ & 70 & 70 \\
3. & Skor rata-rata & 90 & 84 \\
4. & Siswa tuntas & 30 & 20 \\
5. & $\begin{array}{l}\text { Siswa tidak } \\
\text { tuntas }\end{array}$ & 2 & 16 \\
\hline & KKM & \multicolumn{3}{|c}{} \\
\hline
\end{tabular}

Berdasarkan hasil penilaian diri diketahui bahwa hasil penilaian diri siswa kelas model untuk rerata $90 \%$, nilai maksimum sebesar 100 dan nilai minimum 70. Jumlah siswa yang tuntas sebanyak 30 siswa sedangkan siswa yang tidak tuntas sebanyak 2 orang
1. Karakteristik model Discovery Learning Using Survey dengan memanfaatkan potensi local menekankan pada pembelajaran penemuan untuk menemukan konsep dalam mempelajari materi fungi dengan memperhatikan sintak, sistem sosial, sistem pendukung, peran siswa, peran guru, dampak instruksional, dan dampak pengiring. Model Discovery Learning Using Survey mempunyai 8 sintaks yaitu Survey (Outing Class), Stimulasi, Problem Statemen/ Question, Read, Data Collection, Data Processing \& Verivication, Recite/Review, dan Generalization.

2. Kelayakan prototype model pembelajaran biologi Discovery Learning Using Survey dengan memanfaatkan potensi local ditunjukkan melalui hasil validasi dan uji coba skala kecil. Validasi oleh ahli materi diperoleh skor rata-rata $82,5 \%$ kategori baik. Hasil penilaian oleh validator media diperoleh nilai $80 \%$.

3. Keefektifan Model pembelajaran Discovery Learning Using Survey dengan memanfaatkan potensi local dapat dilihat dari adanya peningkatan hasil belajar siswa. Hal ini dibuktikan dengan rerata nilai postest sebesar 87dengan nilai maksimum 96,67 dan nilai minimum 70 untuk kelas model, sedangkan untuk convensional class sebesar 78 dengan nilai maksimum 90 dan nilai minimum 60,00. Penilaian hasil belajar tidak dapat dilakukan dengan tes kemampuan siswa dalam menjawab soal uji kompetensi karena aspek yang dinilai hanya kognitifnya, maka perlu dikembangkan instrument penilaian yang juga menilai aspek afektif dan psikomotor siswa (Pedoman 
Penilaian Kurikulum 2013) Penilaian aspek afektif dan psikomotor pada proses embelajaran menjadi penting untuk diamati agar penilaian terhadap hasil belajar menjadi optimal, tidak hanya terfokus pada aspek kognitif (Dukta, 1982)

Data nilai postest selanjutnya dianalisis menggunakan Independen sample $t$ tes untuk mengetahui keefektifan model pembelajaran. Berdasarkan data hasil analisis tersebut diperoleh signifikan 0,001 , perolehan taraf signifikan tersebut menunjukan bahwa Ho ditolak $(0,001<0,05)$, sehingga dapat disimpulkan terdapat perbedaan signifikan hasil belajar antara kelas model (menggunakan model Discovery Learning Using Survey dengan memanfaatkan potensi lokal dengan convensional class. Berdasarkan analisis hasil posttest diatas, dapat disimpulkan bahwa pembelajaran dengan menggunakan model Discovery Learning Using Survey dengan memanfaatkan potensi lokal pada materi fungi efektif untuk meningkatkan hasil belajar siswa kelas X di SMA. Sesuai dengan pernyataan Hamid (2013) bahwa pengembangan model Guded Discovery lebih efektif dibandingkan dengan metode ceramah dan siswa menjadi lebih aktif dalam menemukan objek yang dipelajari pada materi fungi. Diperkuat oleh Rustaman (2005) menyatakan bahwa keberhasilan suatu pembelajaran ditentukan oleh pendekatan dan model yang dipilih guru sesuai dengan materi yang diberikan.

Tingginya hasil belajar kognitif siswa pada kelas model dibandingkan kelas convensional dikarenakan kegiatan dalam pembelajaran Discovery Learning Using Survey membantu siswa untuk mengalami kebermaknaan belajar. Siswa dituntut tidak hanya mendengar melainkan melakukan aktivitas dan berkomunikasi. Hasil penelitian Magnesen dalam Nicolls (2004:7) menggambarkan tingkat ingatan siswa yang belajar dengan melakukan dan mengkomunikasikannya sangat efektif yaitu mencapai sebesar $90 \%$. Sebaliknya apabila siswa belajar hanya dengan mendengar, membaca atau melihat maka tingkat ingatan siswa kurang dari $50 \%$. Aktivitas-aktivitas yang dilakukan siswa dalam pembelajaran Discovery Learning Using Survey mendukung perkembangan intelektual siswa. Perkembangan intelektual yang dimaksud berkaitan dengan kemampuan dalam pikiran siswa untuk merefleksikan setiap pengalaman yang diperoleh. Sesuai dengan pendapat Meier (2000:50) aktivitas yang mendukung perkembangan intelektual antara lain proses pemecahan masalah, analisa data, pencarian informasi, pengajuan pertanyaan, perencanaan strategi-strategi, dan penerimaan ide-ide baru.

Hasil penelitian menunjukkan bahwa rata-rata nilai afektif siswa pada kelas penerapan model Discovery Learning Using Survey lebih tinggi dibandingkan dengan kelas baseline yang menggunakan model ceramah bervariasi. Rerata yang diperoleh siswa pada kelas penerapan model Discovery Learning Using Survey adalah 85,83, sedangkan pada kelas kelas biasa 79,69.

Sikap yang dikembangkan dalam pembelajaran Discovery Learning Using Survey pada materi fungi antara lain sikap teliti, tanggung jawab, disiplin dan kerjasama. Sikap teliti sangat diperlukan ketika siswa mencari obyek yang akan diamati melalui mikroskop, ketika siswa menyajikan dan mengidentifikasi hasil pengamatannya. Tugas-tugas yang diberikan guru melatih siswa untuk bertanggung jawab, berdisiplin dan bekerjasama. Hal tersebut sejalan dengan hasil penelitian Zulhelmi (2003: ) di mana pembelajaran yang didukung dengan survey lapangan meningkatkan kemampuan afektif siswa. Selain itu, pembelajaran berbasis discovery dapat 
meningkatkan kepercayaan diri pada siswa (Balim, 2009:2)

Data Hasil belajar psikomotor (keterampilan) menunjukkan bahwa rata-rata nilai psikomotorik siswa pada kelas penerapan model Discovery Learning Using Survey lebih tinggi dibandingkan dengan kelas yang menggunakan model ceramah bervariasi. Sehingga dapat disimpulkan bahwa penggunaan model pembelajaran Discovery Learning Using Survey pada materi fungi sangat efektif dalam memberdayakan aspek keterampilan siswa.

Berdasarkan uraian hasil penelitian yang menyatakan bahwa Discovery Learning merupakan faktor yang cemerlang untuk menumbuhkan kontruktivisme modern dan merupakan konsep dasar untuk mengubah pendidikan keperawatan. Didukung oleh hasil penelitian Wouter van Joolingen (1999) discovery learning merupakan instrumen yang mendukung kognitif siswa, dapat menjembatani antara lingkungan belajar terbuka dan lingkungan belajar yang disajikan dalam buku pelajaran. Sehngga menguatkan pengembangan suatu model pembelajaran yang memerlukan lingkungan luar sebagai sumber belajar. Kombinasi beberapa metode pembelajaran yang tepat dan baik dalam suatu proses pembelajaran menjadi efektif untuk digunakan dalam upaya meningkatkan hasil belajar siswa (Ajiboye,1996).

\section{Kesimpulan dan Rekomendasi}

Kesimpulan yang diperoleh dari penelitian dan pengembangan model Discovery Learning Using Survey dengan memanfaatkan potensi lokal adalah sebagai berikut: 1 . Karakteristik model Discovery Learning Using Survey dengan memanfaatkan potensi local menekankan pada pembelajaran penemuan untuk menemukan konsep dalam mempelajari materi fungi dengan memperhatikan sintak, sistem sosial, sistem pendukung, peran siswa, peran guru, dampak instruksional, dan dampak pengiring. 2. Kelayakan prototype model pembelajaran biologi Discovery Learning Using Survey dengan memanfaatkan potensi local ditunjukkan melalui hasil validasi dan uji coba skala kecil yang mengalami peningkatan sehingga layak untuk digunakan sebagai model pembelajaran baru. 3. Berdasarkan rerata yang dihasilkan pada saat pre test dan post test dari kelas model, maka model pembelajaran Discovery Learning Using Survey dinyatakan efektif dalam memberdayakan hasil belajar siswa.

Saran dan perbaikan yang perlu dilakukan, yaitu 1). Penerapan model Discovery Learning Using Survey dengan memanfaatkan potensi local hanya terbatas pada satu sekolah yaitu SMA Negeri 1 Jogorogo Ngawi. Oleh karenanya, perlu adanya penelitian lebih luas mengenai hal tersebut. 2). Model pembelajaran Discovery Learning Using Survey dengan memanfaatkan potensi local pada materi fungi memerlukan pengujian lebih luas (desiminasi dan implementasi) untuk menyempurnaan tahap penelitian pengembangan yang dilakukan. 3). Model pembelajaran Discovery Learning Using Survey dengan memanfaatkan potensi local dapat dikembangkan untuk materi lain yang sesuai.

\section{Daftar Pustaka}

Arends, R.I. (2008). Learning to Teach (Terjemahan) Yogyakarta: Pustaka Pelajar.

Ajiboye,J.O (1996). The Modified lectur Method and student cognitive and affective Outcome in some population Education Concept. Unpblished Ph.D. Thesis Departement of teacher Education Universiy of Ibadan, Ibadan. 
Borg, Walter R \& Gall, Meredith D (1983).

Educational Research- An Introduction. Longman. New York \& London.

Badan Standar Nasional Pendidikan.2009. Laporan Hasil Ujian Nasional. Jakarta Kemendikbud. 2010. Laporan Hasil Ujian Nasional. Jakarta Kemendikbud.

2010. Laporan Hasil Ujian Nasional. Jakarta Kemendikbud.

2010. Laporan Hasil Ujian Nasional. Jakarta Kemendikbud.

Campbell,N.A. et al. 2002. Biologi. Jilid 3. Jakarta:Erlangga

Hamid, Mirza Faisal. (2013). Pengembangan Perangkat Pembelajaran Guided Discovery dengan Pendekatan Contextual Teaching and Learning pada Standar Kompetensi Mengoperasikan Sistem Pengendalian Elektromagnetik Di SMK Negeri 2 Surabaya. Jurnal Pendidikan Teknik Elektro. Vol 02 Nomor 1. 247-253.

Ilahi, Muhammad Takdir. (2012). Pembelajaran Discovery Strategy dan Mental Vocational Skill. Yogyakarta: Diva Press

Kemendikbud. (2013). Materi Pelatihan Guru Implementasi Kurikulum 2013. Hand out: 258-363

Mujiman, Haris. 2009. Belajar Mandiri. Surakarta:LPP UNS dan UNS Press

Prayitno, Baskoro Adi. (2012). Pengembangan Model Pembelajaran Biologi SMA Berbasis Konstruktivis-Kolaboratif untuk Memberdayakan Kemampuan Berpikir Kritis dan Kompetensi Biologi Siswa Berkemampuan Akademik Bawah. Malang: Universitas Negeri Malang

Silberman, Mel. (2001). 101 Strategi Pembelajaran Aktif. Yogyakarta : Pustaka pelajar.

Trianto.2007. Model-model Pembelajaran Inovatif
Konstruktivistik. Jakarta: Prestasi Pustaka

Trianto.2007. Model-model Pembelajaran Inovatif Berorientasi Konstruktivistik. Jakarta: Prestasi Pustaka

Wena,made. 2011. Strategi Pembelajaran Inovatif Kontemporer. Bumi Aksara. Jakarta 